\title{
Értelmi sérültek fogászati állapotának felmérése
}

\author{
Szmirnova Ilona dr. ${ }^{1}$ - Szmirnov György dr. ${ }^{1}$ - Rencz Fanni dr. ${ }^{2}$ \\ Szabó Ákos ${ }^{2,3}$. Trimmel Bálint dr. ${ }^{4}$. Németh Zsolt dr. ${ }^{1}$. Szabó György dr. ${ }^{1}$
}

${ }^{1}$ Semmelweis Egyetem, Fogorvostudományi Kar, Arc-Állcsont-Szájsebészeti és Fogászati Klinika, Budapest

${ }^{2}$ Budapesti Corvinus Egyetem, Egészségügyi Közgazdaságtan Tanszék, Budapest ${ }^{3}$ Semmelweis Egyetem, Rácz Károly Klinikai Orvostudományok Doktori Iskola, Budapest ${ }^{4}$ Semmelweis Egyetem, Fogorvostudományi Kar, Orális Diagnosztikai Tanszék, Budapest

Bevezetés: Magyarországon 100000 olyan értelmi sérült él, akik speciális ellátásra szorulnak. Előzőleg beszámoltunk az akut fogászati ellátás eredményeiról és problémáiról. Ahhoz azonban, hogy a teljes fogászati rehabilitáció felé lépéseket lehessen tenni, ismerni kell az ilyen betegek fogászati állapotát.

Célkitüzés: Statisztikailag releváns, nagyobb beteganyagon felmérni az értelmi sérült betegek fogászati állapotát, összehasonlítva mind az orvosi rehabilitációs kezelésben részesülő betegek (fóleg testi fogyatékosok), mind az általános populáció adataival.

Módszer: A fogászati állapot felmérésére két betegcsoport állt rendelkezésünkre. Összesen 325 beteg statusát rögzítettük. A vizsgáltakat 3 csoportba osztottuk: enyhe (36), közepes (247) és súlyos (42) értelmi sérültek. Az értelmi sérült betegek fogászati állapotát DMF-T-indexszel mértük, és összehasonlítottuk az orvosi rehabilitációs kezelésben részesülő betegek és az általános populáció adataival is.

Eredmények: A 325 szellemi sérült össz-DMF-T-indexének átlaga \pm szórás: 11,04 \pm 7,35; a carieses fogak számának átlaga: $\mathrm{D}=3,66 \pm 4,61$; a hiányzó fogak számának átlaga: $\mathrm{M}=5,22 \pm 5,74$. A fogmegtartó kezelés minimális volt: átlag $\mathrm{F}=2,16 \pm 3,12$. Azoknak az értelmi sérülteknek, akik intézetben élnek, rosszabb a fogazati állapotuk, mint azoknak, akik családban vannak.

Következtetések: Az eredményekból látszik, hogy az értelmi sérültek fogai elhanyagoltabbak, mint a normálpopuláció esetében. A DMF-T-index önmagában nem tükrözi ezeket a magállapításokat, csak akkor, ha szétbontva vizsgáljuk az adatokat.

Orv Hetil. 2021; 162(42): 1698-1702.

Kulcsszavak: értelmi sérültek, fogászati kezelés, DMF-T-index

\section{Dental survey of the mentally disabled patients}

Introduction: There are 100,000 mentally disabled individuals in Hungary requiring special care. Previously, we reported the results and problems of acute dental care. However, in order to take the appropriate measures toward holistic dental rehabilitation, clarity regarding the condition of those mentally disabled individuals is necessary.

Objective: To measure the dental health of mentally disabled individuals based on a large sample of patients, to compare the results with both differently-abled (i.e., primarily physically disabled) individuals and the general population. Methods: There were two available patient cohorts for the measurement of dental health. With the two cohorts combined, we recorded data about 325 patients. We split the patients into three groups: mild (36), medium (247), and severe (42) mental disability. We used DMF-T index to measure dental health status, and compared the results with those of physically disabled and the general population.

Results: The mean \pm deviation of DMF-T index of the disabled patients was $11.04 \pm 7.35$; the mean of decayed teeth: $\mathrm{D}=3.66 \pm 4.61$; the missing teeth: $\mathrm{M}=5.22 \pm 5.74$; the filled teeth: $\mathrm{F}=2.16 \pm 3.12$. Mentally disabled patients living in institutions showed worse dental health than those living with families.

Conclusions: The results show that the teeth of mentally disabled patients are more neglected than those of the general population. The DMF-T index does not mirror these conclusions unless we examine each data set separately.

Keywords: mentally disabled, dental care, DMF-T index

Szmirnova I, Szmirnov Gy, Rencz F, Szabó Á, Trimmel B, Németh Zs, Szabó Gy. [Dental survey of the mentally disabled patients]. Orv Hetil. 2021; 162(42): 1698-1702.

(Beérkezett: 2021. február 15.; elfogadva: 2021. március 24.) 


\section{Rövidítések}

ANOVA $=$ (analysis of variance $)$ varianciaanalízis; DMF-T $=$ (decayed, missing, filled tooth) szuvas, hiányzó, tömött fog

\section{Elözmények}

Előző közleményünkben beszámoltunk az értelmi sérülteknek (az értelmi fogyatékkal élők definíciójáról előző közleményünkben részletesen írtunk) a Semmelweis Egyetem Fogorvostudományi Karának Arc-ÁllcsontSzájsebészeti és Fogászati Klinikáján meglévő kezelési lehetőségéről [1]. Öt év alatt (2014-2019) a Klinika Rehabilitációs Osztályán csaknem 1800 beteg került akut ellátásra.

A kezelések döntő többsége fogeltávolításból, sebészi feltárásból, a fogak gyulladásos megbetegedéseinek gyógyításából állt. Tekintettel arra, hogy a beavatkozások nagy része csak altatásban volt kivitelezhető, fogtömés, fogpótlás idő és technikai problémák miatt csak kevés esetben volt lehetséges.

Az értelmi sérültek számára az akut ellátás altatásban való biztosítása nagy előrelépés, a teljes fogászati rehabilitáció viszont még a legfejlettebb országokban is problémát jelent. A nemzetközi irodalomban számos cikk tesz erról tanúságot [2-10].

Magyarországon a Központi Statisztikai Hivatal 2011. évi népszámlálása szerint közel 100000 olyan értelmi sérült él, akik speciális ellátásra szorulnak [11]. Ahhoz, hogy az értelmi sérültek teljes körü fogászati kezelésében előre lehessen lépni, mindenekelőtt fel kell mérni a betegek valós szükségleteit. Ez számos országban, így Magyarországon sem történt meg eddig.

Ez annak ellenére így van, hogy Orsós és mtsai [12] az általános fogyatékkal élők orális egészségügyi állapotáról 2018-ban tanulmányt készítettek. Az ő munkájukban 608, fogyatékkal élő között 13 olyan beteg volt, akik egy „Pszichoszomatikus és Pszichoterápiás Rehabilitációs Osztályról” kerültek ki. Ez is igazolja, hogy szükség van külön is az értelmi sérültek fogászati állapotának felmérésére, mivel az ő kezelésük több és nagyobb feladatot jelent, mint a testi fogyatékkal élők ellátása.

\section{Betegek és módszer}

A fogászati állapot felmérésére két betegcsoport állt rendelkezésünkre: az egyik csoportot a 2019. július 01. és 2020. február 10. között az Arc-Állcsont-Szájsebészeti és Fogászati Klinika Rehabilitációs Osztályán akut ellátásra megjelent 281 értelmi sérült beteg alkotta, a másik csoportot pedig 44 olyan beteg, akiket az „Egyenlo Esélyekért Alapítvány Fogyatékosok Otthona és Nappali Gondozó" nevü intézetben vizsgáltunk.

Így összesen 325 beteg fogászati statusát rögzítettük (53,7\% férfi). Az átlagéletkor 33,77 \pm 9,98 év volt (minimum 18, maximum 69). A vizsgáltakat a beküldő ideggyógyász vagy pszichiáter diagnózisa alapján 3 csoportba osztottuk: enyhe (36), közepes (247) és súlyos (42) értelmi sérültek csoportjába. Voltak közöttük olyan betegek, akik családban éltek (171), és voltak, akik intézetben (154). Az adatok pontossága érdekében a fizikális vizsgálatot ugyanazon betegnél két orvos egymástól függetlenül végezte.

A DMF-T-index megállapítását $(\mathrm{D}=$ decayed; $\mathrm{M}=$ missing; $\mathrm{F}=$ filled; $\mathrm{T}$ = tooth) fogászati tükör, szonda és vizsgálólámpa segítségével kiviteleztük. A hiányzó fogak tekintetében a bölcsességfogakat nem vettük figyelembe.

A vizsgálatokat etikai engedély (IV/8158-3/2020/ EKU) és szülői vagy gondozói engedély birtokában végeztük.

Eredményeinket egyrészt a magyarországi átlagpopuláció DMF-T-adataival [13], másrészt az általános fogyatékosok fogászati állapotával [12] hasonlítottuk össze. Az általános populációval kapcsolatban több közlemény áll rendelkezésünkre [13-15]. Mi az összehasonlító vizsgálathoz Madléna és mtsai eredményeit használtuk fel [13].

\section{Statisztikai elemzés}

Elsőként meghatároztuk a D-, M-, F- és DMF-T-index átlagát és szórását. A betegek D-, M-, F- és DMF-T-indexét kétmintás t-próbával az általános populáció nemben és korban illesztett pontszámához viszonyítottuk. Szintén kétmintás t-próbával hasonlítottuk össze a családban és az intézetben élő betegek pontszámait. A D-, M-, F- és DMF-T-index és a fogyatékosság súlyossági fokának összefüggését egyszempontos varianciaanalízissel (ANOVA) vizsgáltuk. A statisztikai elemzéseket 5\%os szignifikanciaszinten végeztük. A számításokat az SPSS Statistics 25.0 programcsomaggal (IBM Corporation, Armonk, NY, Amerikai Egyesült Államok) végeztük.

\section{Eredmények}

A 325 szellemi sérült össz-DMF-T-indexének átlaga \pm szórás: 11,04 $\pm 7,35$; a carieses fogak számának átlaga: $\mathrm{D}=3,66 \pm 4,61$; a hiányzó fogak számának átlaga: $\mathrm{M}=$ $5,22 \pm 5,74$. A fogmegtartó kezelés minimális volt: átlag $\mathrm{F}=2,16 \pm 3,12$ (1. táblázat).

Minél súlyosabb az értelmi fogyatékosság foka, annál rosszabb a fogazati status. A súlyos fogyatékosságú csoportban szignifikánsan több carieses foga van a betegeknek (enyhe: $\mathrm{D}=3,19 \pm 3,18$; közepes: $\mathrm{D}=3,41 \pm 4,02$; súlyos: $\mathrm{D}=5,52 \pm 7,63 ; \mathrm{p}=0,0184)$.

Fiatalabb korban a carieses fogak átlagos száma magasabb, később az eltávolított fogak átlagos száma dominál (2. táblázat).

Különbség van az intézetben és a családban élők fogazati állapota között. A családban lévők fogai szignifikánsan jobb állapotban vannak, DMF-T-indexük: 9,76 \pm 6,76 vs. $12,39 \pm 7,77(\mathrm{p}=0,0013)$ (3. táblázat). 
1. táblázat |Az értelmi sérült páciensek D-, M-, F-mutatói és DMF-T-indexének átlaga \pm szórás

\begin{tabular}{llllll}
\hline & $\mathrm{n}(\%)$ & $\mathrm{DMF}-\mathrm{T}$ & $\mathrm{D}$ & $\mathrm{M}$ & $\mathrm{F}$ \\
\hline Teljes minta & 325 & $11,04 \pm 7,35$ & $3,66 \pm 4,61$ & $5,22 \pm 5,74$ & $2,16 \pm 3,12$ \\
\hline Enyhe & $36(11,1 \%)$ & $11,00 \pm 6,73$ & $3,19 \pm 3,18$ & $5,17 \pm 7,06$ & $2,64 \pm 2,46$ \\
\hline Közepes & $247(76,0 \%)$ & $10,72 \pm 7,20$ & $3,41 \pm 4,02$ & $5,24 \pm 5,58$ & $2,07 \pm 3,13$ \\
\hline Súlyos & $42(12,9 \%)$ & $12,98 \pm 8,49$ & $5,52 \pm 7,63$ & $5,14 \pm 5,50$ & $2,31 \pm 3,56$ \\
\hline ANOVA-p-érték & - & 0,1849 & $0,0184^{*}$ & 0,9934 & 0,5627 \\
\hline
\end{tabular}

*Egyszempontos varianciaanalízis (ANOVA) p<0,05; azt jelzi, hogy a betegek átlaga szignifikánsan eltér a súlyossági csoportok között.

DMF-T = szuvas, hiányzó, tömött fog

2. táblázat | A betegek nem és korcsoport szerinti felosztása a D-, M-, F-mutatók és a DMF-T vonatkozásában $(\mathrm{n}=325)$

\begin{tabular}{|c|c|c|c|c|c|c|c|c|c|c|}
\hline \multirow[t]{2}{*}{ Korcsoport (év) } & \multirow[t]{2}{*}{ Betegek } & \multirow[t]{2}{*}{$\mathrm{n}$} & \multicolumn{2}{|c|}{ DMF-T } & \multicolumn{2}{|c|}{$\mathrm{D}$} & \multicolumn{2}{|c|}{ M } & \multicolumn{2}{|c|}{$\mathrm{F}$} \\
\hline & & & Átlag & Szórás & Átlag & Szórás & Átlag & Szórás & Átlag & Szórás \\
\hline \multirow[t]{3}{*}{$\leq 19$} & Férfi & 8 & $3,00 *$ & 2,39 & 2,63 & 2,39 & 0,25 * & 0,71 & $0,13^{*}$ & 0,35 \\
\hline & Nő & 3 & 14,33 & 9,71 & $14,00 *$ & 10,15 & $0,33^{*}$ & 0,58 & $0,00^{*}$ & 0,00 \\
\hline & Összesen & 11 & $6,09 *$ & 7,13 & 5,73 & 7,27 & $0,27^{*}$ & 0,65 & $0,09 *$ & 0,30 \\
\hline \multirow[t]{3}{*}{$20-34$} & Férfi & 87 & $8,99 *$ & 6,29 & 3,70 & 4,70 & 3,17 & 3,66 & 2,11 & 3,41 \\
\hline & Nö & 83 & $9,45^{*}$ & 6,41 & 3,32 & 3,91 & 3,82 & 3,83 & 2,43 & 2,85 \\
\hline & Összesen & 170 & $9,21^{*}$ & 6,33 & 3,51 & 4,32 & 3,49 & 3,75 & 2,27 & 3,14 \\
\hline \multirow[t]{3}{*}{$35-44$} & Férfi & 56 & 12,02 * & 6,68 & 3,52 & 4,28 & 6,04 & 4,98 & 2,46 & 3,48 \\
\hline & Nő & 47 & $11,79 *$ & 6,94 & 3,98 & 5,20 & 5,30 & 5,04 & 2,51 & 3,15 \\
\hline & Összesen & 103 & 11,91 * & 6,77 & 3,73 & 4,71 & 5,70 & 4,99 & 2,49 & 3,32 \\
\hline \multirow[t]{3}{*}{$45-64$} & Férfi & 21 & 16,38 & 8,78 & 3,95 & 5,43 & 10,90 & 8,31 & 1,52 & 2,52 \\
\hline & Nő & 17 & 17,41 & 8,05 & 2,47 & 3,48 & 13,12 & 7,62 & 1,82 & 3,09 \\
\hline & Összesen & 38 & 16,84 & 8,37 & 3,29 & 4,66 & 11,89 & 7,98 & 1,66 & 2,75 \\
\hline \multirow[t]{3}{*}{$65-74$} & Férfi & 2 & 28,00 & 0,00 & 9,50 & 3,54 & 18,50 & 3,54 & 0,00 & 0,00 \\
\hline & Nő & 1 & 28,00 & - & 0,00 & - & 28,00 & - & 0,00 & - \\
\hline & Összesen & 3 & 28,00 & 0,00 & 6,33 & 6,03 & 21,67 & 6,03 & 0,00 & 0,00 \\
\hline
\end{tabular}

*Kétmintás t-próba p<0,05; azt jelzi, hogy a betegek átlaga szignifikánsan eltér a nemben és korban illesztett általános populációétól.

DMF-T = szuvas, hiányzó, tömött fog

\section{Megbeszélés}

Annak ellenére, hogy a fogyatékkal élők akut fogászati ellátása az utóbbi években Magyarországon is sokat javult ( 5 centrumban öt év alatt közel 3000 beteget láttak el), a teljes fogászati rehabilitáció lehetőségei nagyon korlátozottak.

Mint ahogy a bevezetőben is említettük, az előrelépéshez szükség van a fogyatékkal élők fogászati állapotának objektív adataira.

Vizsgálatainkban több mint 300-an vettek részt. Ez a szám nagyjából megfelel a nemzetközi irodalomban ismerteknek: Indiában 225 [2], Németországban 221, illetve 207 beteget vizsgáltak [3]. Micheelis és Schiffner [10] megállapították, hogy az értelmi sérült pácienseknek több a carieses és hiányzó foguk, de kevesebb tömött, illetve koronával ellátott foguk van. A DMF-T-index így az általános populáció esetében 14,5, az értelmi sérülteknél pedig 13,6 volt. Pieper és mtsai (1986) szerint 19,7 volt azoknak a súlyos szellemi sérülteknek a
DMF-indexe, akiket speciális intézetekben kezeltek [8]. Kimutatták, hogy az intézetben levő betegeknek roszszabbak a fogaik, mint azoknak, akik családban vannak. Ez korrelál a mi adatainkkal is.

3. táblázat A családban és az intézetben élő betegek fogászati statusa ( $\mathrm{n}=$ 325)

\begin{tabular}{l|c|c|c|c|c}
\hline \multirow{2}{*}{} & \multicolumn{2}{|c|}{ Család $(\mathrm{n}=171)$} & \multicolumn{2}{c|}{ Intézet $(\mathrm{n}=154)$} & \multirow{2}{*}{$\begin{array}{c}\text { Kétmintás } \\
\text { t-próba, p-érték }\end{array}$} \\
\cline { 2 - 5 } & Átlag & Szórás & Átlag & Szórás & \\
\hline DMF-T & 9,76 & 6,76 & 12,39 & 7,77 & $0,0013^{*}$ \\
D & 3,16 & 4,26 & 4,22 & 4,92 & $0,0392 *$ \\
M & 4,33 & 4,49 & 6,21 & 6,74 & $0,0037 *$ \\
F & 2,27 & 3,09 & 2,04 & 3,16 & 0,4970 \\
\hline
\end{tabular}

* Kétmintás t-próba $\mathrm{p}<0,05$; azt jelzi, hogy a fogazati állapotot illetően a tömések kivételével szignifikáns különbség van a családban élők javára.

DMF-T = szuvas, hiányzó, tömött fog 


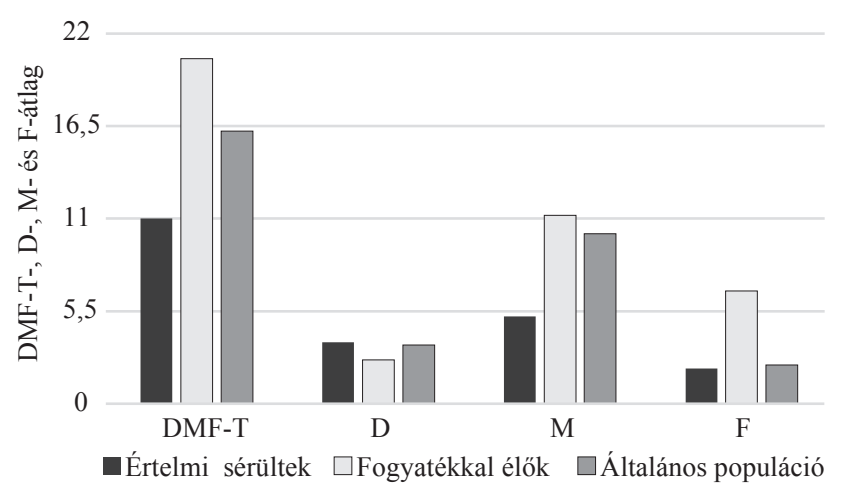

1. ábra $\mid$ Az értelmi sérültek, a fogyatékkal élők és az általános populáció fogászati statusának eredményei

Az értelmi sérültek $(\mathrm{n}=325)$, a fogyatékkal élők $(\mathrm{n}=608)$ és az általános populáció $(\mathrm{n}=4606)$ fogászati statusának eredményei $[12,13]$

DMF-T = szuvas, hiányzó, tömött fog

Indiai adatok [2] szerint a fogyatékkal élók fogazati állapota függ a családi viszonyoktól, a tanultabb környezet pozitív hatása mutatható ki. Bizonyos tekintetben ez összhangban van a Baden-Württembergben és Szászországban végzett vizsgálatokkal. A fogyatékkal élőknek a Német Demokratikus Köztársaság egykori területén (így Szászországban is) rosszabb a fogászati statusuk, mint a nyugati tartományokban élőké. A fogyatékkal élők D-, M- és F-értékei és az életkori különbségei jól mutatják, hogy fiatalabb korban több a carieses fog, amit nem kezelnek, és azokat később el kell távolítani. Így az idősebb korosztályok esetében a hiányzó fogak dominálnak [3].

Bár eredeti célkitűzéseink között csak az értelmi sérültek és az általános populáció fogazati állapotának összehasonlítása szerepelt, érdekesnek tartottuk eredményeinknek az általános fogyatékkal élők (fóleg testi fogyatékosok) adataival való összehasonlítását is. Tehát mennyiben hasonló vagy eltérő a három csoport?

Míg az általános populáció (4606 vizsgált személy) DMF-T-indexének átlaga 16,2, addig a 608, általános fogyatékkal élőnél ugyanez 20,5, a 325 vizsgált, értelmi fogyatékkal élőnél pedig 11 volt. Összehasonlítva a szellemi sérültek, az általános fogyatékkal élők és az általános populáció fogászati állapotát, azt láthatjuk, hogy a legtöbb carieses foga, a legkevesebb tömött foga és a legke-

4. táblázat | A DMF-T-index átlaga \pm szórás értékek összehasonlítása az értelmi sérültek és az általános populáció 19-44 éves korcsoportjában

\begin{tabular}{lrc}
\hline \multirow{2}{*}{ Korcsoport (év) } & \multicolumn{2}{c}{ DMF-T } \\
\cline { 2 - 3 } & Értelmi sérültek & Általános populáció \\
\hline$\leq 19$ & $6,09 \pm 7,13$ & $11,24 \pm 4,85$ \\
$20-34$ & $9,21 \pm 6,33$ & $12,76 \pm 5,45$ \\
$35-44$ & $11,91 \pm 6,77$ & $15,40 \pm 5,13$ \\
\hline
\end{tabular}

DMF-T = szuvas, hiányzó, tömött fog vesebb hiányzó foga is az értelmi sérülteknek van ( 1 . ábra) $[12,13]$.

Érdemes összehasonlítani a 20-44 éves korcsoportba tartozó szellemi fogyatékosok, általános fogyatékosok és átlagpopuláció fogazati állapotát, tekintettel arra, hogy ebbe a csoportba tartozott a vizsgáltak több mint $85 \%$-a. Ilyen szempontból sajnos csak az általános népesség fogászati állapotának részletezéséről van irodalmi adatunk, az általános fogyatékkal élőkről nincs. A DMF-T-index átlagértékének alakulását a $\leq 19$ évesek korcsoportjában a szellemi sérültek $v$ s. általános populáció átlaga \pm szórás a következő $6,09 \pm 7,13$ vs. $11,24 \pm 4,85$; a 20-34 éveseknél 9,21 $\pm 6,33$ vs. $12,76 \pm 5,45$, a 35-44 évesek csoportjába tartozó betegeknél pedig $11,91 \pm 6,77$ vs. $15,40 \pm 5,13$ eredmények figyelhetők meg [13] (4. táblázat).

Ennek a látszólagos paradoxonnak a magyarázatát akkor érthetjük meg, ha a DMF-T-indexet szétbontjuk. A carieses fogak számának átlaga a szellemi sérültek esetében a legmagasabb $(\mathrm{D}=3,7)$. Fogászati kezelésük megszervezése komplikáltabb, a legtöbb esetben altatást igényel, ezért ellátásuk során a leggyakrabban csak fogeltávolítást végeztek $(M=5,2)$, fogmegtartó kezelést alig $(\mathrm{F}=2,2)$. Az általános populáció esetében $\mathrm{F}=2,3$ a tömött fogak számának átlaga, a carieses fogak aránya a legalacsonyabb $(\mathrm{D}=3,5)$, a hiányzó fogaké $\mathrm{M}=10,1$.

Az általános fogyatékkal élők adataiban a hiányzó fogak száma dominál $(M=11,2)$, emellett a tömött fogak száma is több $(\mathrm{F}=6,7)$, ezért olyan magas a DMF-Tindexük. Ez azt jelenti, hogy panasz esetén fóleg extractióra kerül sor, de a fogmegtartó kezelést is sokkal könynyebb kivitelezni, mint az értelmi sérültek esetében (nem kell hozzá altatás).

\section{Következtetés}

A fentieket az irodalmi adatokkal [5, 10] egybevetve megállapíthatjuk, hogy a DMF-T-index összességében nem ad kelló felvilágosítást az értelmi sérültek fogazati állapotáról, ha azt az általános populációval akarjuk öszszehasonlítani. A DMF-T-indexet szét kell bontani, hogy láthassuk, az értelmi sérültek esetében több a carieses fog, az életkor előrehaladtával egyre több a foghiányuk, és kevesebb restaurált foguk figyelhető meg az általános populációval szemben.

A rágófunkció megtartása szempontjából fontos lenne nemcsak az akut fogászati ellátásuk, hanem a fogászati rehabilitációjuk is. Ez a jelenlegi kapacitások mellett csak korlátozottan biztosítható. Ezért az irodalommal összefüggésben hangsúlyozni szeretnénk, hogy a prevenciónak nagy jelentősége lenne, részben, hogy kevesebb akut ellátásra legyen szükség [8-10], részben, hogy a szúkös (altatás!) lehetőségeket figyelembe véve kevesebb beteg várjon a fogászati rehabilitációra.

A rehabilitációs lehetőségekről, eddigi eredményeinkről a következőkben kívánunk beszámolni. 
Anyagi támogatás: A közlemény megírása, illetve a kapcsolódó kutatómunka anyagi támogatásban nem részesült.

Szerzői munkamegosztás: Sz. I., Sz Gy.: Gyakorlati munka, a dolgozat megírása. R. F., Sz. Á.: Statisztikai elemzés. T. B.: Irodalomkutatás. N. Zs.: Ötletadó. Sz. Gy.: Szakmai felügyelet. A cikk végleges változatát valamenynyi szerző elolvasta és jóváhagyta.

Érdekeltségek: A szerzőknek nincsenek érdekeltségeik.

\section{Irodalom}

[1] Szmirnova I, Gellérd E, Pintér GT, et al. Dental and dental oral surgical treatment of the mentally retarded in Hungary: the situation in the past, currently and hopes for the future. [A szellemi fogyatékosok fogászati-szájsebészeti ellátásának múltja, jelene és a remélt jövője Magyarországon.] Orv Hetil. 2019; 160: 13801386. [Hungarian]

[2] Chhajed S, Bhambhani G, Agarwal R, et al. Impact of various extra-oral factors on caries experience among mentally disabled children residing in Bhopal city, central India: a cross-sectional study. J Indian Soc Pedod Prev Dent. 2016; 34: 285-290.

[3] Schulte AG, Freyer K, Bissar A. Caries experience and treatment need in adult with intellectual disabilities in two German regions. Community Dent Health 2013; 30: 39-44.

[4] Solanki N, Kumar A, Awasthi N, et al. Assessment of oral status in pediatric patients with special health care needs receiving dental rehabilitation procedures under general anesthesia: a retrospective analysis. J Contemp Dent Pract. 2016; 17: 476-479.

[5] Chang J, Lee JH, Son HH, et al. Caries risk profile of Korean dental patients with severe intellectual disabilities. Spec Care Dentist. 2014; 34: 201-207.

[6] Sitkin SI, Gasparian AL, Ivanova TI, et al. Long-term dental interventions in mentally retarded children under general anesthesia with sevoflurane. [Проведение Алительных стоматологических вмешательств у детей с задержкой умственного развития в условиях общей анестезии севофмюраном.] Stomatologiia (Mosk). 2015; 94: 59-60. [Russian]
[7] Naouri D, Bussiere C, Pelletier-Fleury N. What are the determinants of dental care expenditures in institutions for adults with disabilities? Findings from a national survey. Arch Phys Med Rehabil. 2018; 99: 1471-1478.

[8] Pieper K, Dirks B, Kessler P. Caries, oral hygiene and periodontal disease in handicapped adults. Community Dent Oral Epidemiol. 1986; 14: 28-30.

[9] Mac Giolla Phadraig C, Nunn J, Dougall A, et al. What should dental services for people with disabilities be like? Results of an Irish Delphi panel survey. PLoS ONE 2014; 9: ell3393.

[10] Schiffner U. Krankheits- und Versorgungsprävalenzen bei Erwachsenen (35-44 Jahre). In: Micheelis W, Schiffner U. Vierte Deutsche Mundgesundheitsstudie (DMS IV). Institut der Deutschen Zahnärzte, Köln, 2006; pp. 241-265.

[11] Hungarian Central Statistical Office. 2011 population census 11. Disabled persons. [Központi Statisztikai Hivatal. 2011. évi népszámlálás - 11. Fogyatékossággal élők.] Központi Statisztikai Hivatal, Budapest, 2014. Available from: http://www.ksh.hu/ nepszamlalas/fogyatekossag_sb [accessed: March 2, 2018]. [Hungarian]

[12] Orsós M, Moldvai J, Kivovics P, et al. Oral health related quality of life of patients undergoing physical medicine and rehabilitation. [Orvosi rehabilitációs kezelésben részesülő betegek orális egészségügyi állapotának vizsgálata.] Orv Hetil. 2018; 159: 2202-2206. [Hungarian]

[13] Madléna M, Hermann P, Jáhn M, et al. Caries prevalence and tooth loss in Hungarian adult population: results of a national survey. BMC Public Health 2008; 8: 364.

[14] Czukor J. National Oral Health Pathfinder surveys in Hungary in the years 1985 and 1991. [WHO epidemiológiai vizsgálatok Magyarországon 1985-ben és 1991-ben.] Fogorv Szle. 1994; 87: 223-235. [Hungarian]

[15] Szőke J, Petersen PE. Oral health status of adults and elderly in Hungary. [A hazai felnőtt- és időskorú lakosság orális egészségi állapota az ezredfordulón.] Fogorv Szle. 2004; 97: 219-229. [Hungarian]

(Szmirnova Ilona dr., Budapest, Mária u. 52., 1085 e-mail: szmirnova@gmail.com)

\section{"Benignus etiam causam dandi cogitat." (A jótékonyság még okot is keres, hogy adhasson.)}

A cikk a Creative Commons Attribution 4.0 International License (https://creativecommons.org/licenses/by/4.0/) feltételei szerint publikált Open Access közlemény, melynek szellemében a cikk bármilyen médiumban szabadon felhasználható, megosztható és újraközölhetö, feltéve, hogy az eredeti szerző és a közlés helye, illetve a CC License linkje és az esetlegesen végrehajtott módositások feltüntetésre kerülnek. (SID_1) 